\title{
PENGARUH PENGETAHUAN STANDAR AKUNTANSI KEUANGAN ENTITAS MIKRO KECIL DAN MENENGAH (SAK EMKM), COMPUTER SELF-EFFICACY, DAN FACILITATING CONDITIONS TERHADAP MINAT MENGGUNAKAN APLIKASI AKUNTANSI (Studi Kasus pada Usaha Mikro Kecil Dan Menengah di Kabupaten Subang)
}

\author{
Fazrin Defillaleti ${ }^{1)}$, Bambang Sugiharto ${ }^{2)}$, Indah Umiyati ${ }^{3)}$ \\ Sekolah Tinggi Ilmu Ekonomi Sutaatmadja, Indonesia \\ Email : fazrindefilla98@gmail.com,bambangsugihart@gmail.com, \\ indahumiyati@gmail.com
}

\begin{abstract}
Small and Medium-Sized Enterprises in Indonesia will continue to grow from year to year, which will support Indonesia's economy. The aim of this research was to find out and analyze the influence of knowledge effects of Financial Accounting Standards of Small and Medium-Sized Enterprises (SMEs), Computer Selfefficacy, and Facilitating Conditions to the intention to using accounting applications Small and Medium-Sized Enterprises (SMEs). The study used three independent variables that are the knowledge of Financial Accounting Standards of Small and Medium-Sized Enterprises (SMEs), Computer Self-efficacy, and Facilitating Conditions, while intention to using accounting applications as a dependent variable. The sample of this research were Small and Medium-Sized Enterprises (SMEs) in Subang Regency, West Java Province. Sampling Incidental of non-probability sampling was used as a sampling method with the total sample of 205 people. Validity, reliability, descriptive analysis, classical assumption test, and multiple regression analysis is used for this study. The results of this research indicate that knowledge of Financial Accounting Standards of Small and Medium-Sized Enterprises (SMEs), Computer Self-efficacy, and Facilitating Conditions have a positive effect to the intention in using either accounting application, the results of tests on each variable or simultaneously.
\end{abstract}

Keyword: Knowledge of Financial Accounting Standards of Small and MediumSized Enterprises (SMEs); Computer Self-efficacy; Facilitating Conditions; Intention To Use; Accounting Application

\begin{abstract}
Abstrak
Usaha Mikro, Kecil, dan Menengah di Indonesia akan terus berkembang dari tahun ke tahun, yang bakal menjadi penunjang perekonomian Indonesia. Tujuan
\end{abstract}

* Corresponding author's e-mail: bambangsugihart@gmail.com

http://openjournal.unpam.ac.id/index.php/JABI 
Jurnal Akuntansi Berkelanjutan Indonesia - Vol. 3, No. 1, Jan 2020 - Defillaleti; Sugiharto \& Umiyati

dari penelitian ini adalah untuk mengetahui dan menganalisis pengaruh pengaruh pengetahuan dari Standar Akuntansi Keuangan Usaha Kecil dan Menengah (UKM), Self-efficacy Komputer, dan Fasilitasi Kondisi terhadap minat menggunakan aplikasi akuntansi Usaha Kecil dan Menengah (UKM). Penelitian ini menggunakan tiga variabel independen yaitu pengetahuan Standar Akuntansi Keuangan Usaha Kecil dan Menengah (UKM), Self-efficacy Komputer, dan Kondisi Fasilitasi, sementara minat menggunakan aplikasi akuntansi sebagai variabel dependen. Sampel penelitian ini adalah Usaha Kecil dan Menengah (UKM) di Kabupaten Subang, Provinsi Jawa Barat. Pengambilan sampel menggunakan non-probabilitas dengan total sampel 205 orang. Validitas, reliabilitas, analisis deskriptif, uji asumsi klasik, dan analisis regresi berganda digunakan untuk penelitian ini. Hasil penelitian ini menunjukkan bahwa pengetahuan Standar Akuntansi Keuangan Usaha Kecil dan Menengah (UKM), Efikasi Diri Komputer, dan Kondisi Fasilitasi memiliki pengaruh positif terhadap niat dalam menggunakan salah satu aplikasi akuntansi, hasil pengujian pada masing-masing variabel atau secara bersamaan.

Kata kunci: Pengetahuan Standar Akuntansi Keuangan Usaha Kecil dan Menengah (UKM); Self-efficacy Komputer; Kondisi Fasilitasi; Minat Menggunakan; Niat Menggunakan; Aplikasi Akuntansi

\section{PENDAHULUAN}

Usaha Mikro, Kecil, dan Menengah di Indonesia akan terus berkembang dari tahun ke tahun, yang bakal menjadi penunjang perekonomian Indonesia. Usaha Mikro, Kecil, dan Menengah memiliki potensi yang sangat besar dalam menyediakan lapangan pekerjaan dan meningkatkan kesejahteraan masyarakat di negara ini. Jumlah pelaku Usaha Mikro, Kecil, dan Menengah (UMKM) tahun 2017 sebanyak 62.922.617 di Indonesia. Terjadi peningkatan sebesar 1.271.440 unit usaha dari tahun sebelumnya yaitu 2016. Sedangkan usaha besar hanya memiliki 5.460 unit usaha di Indonesia. Usaha Mikro, Kecil, dan Menengah menarik sumber daya manusia sebanyak 116.673.416, lebih tinggi dari tahun sebelumnya. Dilihat dari Produk Domestik Bruto (PDB) atas dasar harga berlaku, Usaha Mikro, Kecil, dan Menengah mendapat 7.704.635,9 milyar peningkatan sekitar 695.352,9 milyar. sedangkan usaha besar lebih rendah sebesar 5.136.223,1 milyar (Data kementerian Koperasi dan Usaha Mikro, Kecil, dan Menengah: Perkembangan Data Usaha Mikro, Kecil, dan Menengah (UMKM) dan Usaha Besar (UB) Tahun 2012-2017).

Keberadaan Usaha Mikro, Kecil, dan Menengah di Kabupaten Subang saat ini semakin luas dan beragam. Di kutip dari Dinas Koperasi dan Usaha Kecil Kabupaten Subang tahun 2017, jumlah Usaha Mikro, Kecil, dan Menengah (UMKM) di Kabupaten Subang yang tercatat sebesar 29.236 unit usaha. Unit usaha mikro di Kabupaten Subang sebesar 23.788 unit, usaha kecil sebesar 4.302

* Corresponding author's e-mail: bambangsugihart@gmail.com

http://openjournal.unpam.ac.id/index.php/JABI 
Jurnal Akuntansi Berkelanjutan Indonesia - Vol. 3, No. 1, Jan 2020 - Defillaleti; Sugiharto \& Umiyati

unit, dan usaha menengah sebesar 1.146 unit. Dengan berkembangnya teknologi dapat mempermudah para pengusaha untuk memasarkan produk usaha nya, tetapi persaingan akan menguat sesuai dengan pertumbuhan Usaha Mikro, Kecil, dan Menengah (UMKM) serta era perdagangan bebas seperti Masyarakat Ekonomi ASEAN (MEA). Desakan persaingan terbuka harus disikapi serius oleh perusahaan, di mana kemampuan perusahaan dalam bersaing harus ditingkatkan. Termasuk keahlian dalam menyusun laporan keuangan yang baik.

Kinerja suatu unit usaha diukur melalui pencatatan berupa laporan keuangan menurut standar yang berlaku. Pada tanggal 1 Januari 2018, Ikatan Akuntansi Indonesia (IAI) mulai memberlakukan secara efektif Standar Akuntansi Keuangan Entitas Mikro, Kecil, dan Menengah (SAK EMKM) ditujukan untuk digunakan oleh entitas yang tidak atau belum mampu memenuhi persyaratan akuntansi yang diatur dalam Standar Akuntansi Keuangan Entitas Tanpa Akuntan Publik (SAK ETAP). Standar Akuntansi Keuangan Entitas Mikro, Kecil, dan Menengah (ED SAK EMKM) diharapkan dapat membantu pelaku Usaha Mikro, Kecil, dan Menengah (UMKM) di seluruh Indonesia dalam menyusun laporan keuangannya dengan tepat tanpa harus terjebak dalam kerumitan standar akuntansi yang ada saat ini.

Berdasarkan hasil penelitian sederhana Center of Excellence Sekolah Tinggi Ilmu Ekonomi Sutaatmadja bidang perpajakan pada tahun 2017, bahwa pengusaha mikro, kecil, dan menengah mengalami kesulitan dalam merencanakan keuangannya karena kurangnya pengetahuan tentang akuntansi. Penyusunan keuangan yang masih sederhana dengan hanya mencatat jumlah pengeluaran atau jumlah pendapatan yang diterima. Mereka menerangkan bahwa untuk menentukan laba usaha dengan cara pendapatan dikurangi pengeluaran. Sama halnya dalam penelitian Ningtyas (2017) bahwa pemilik Usaha Mikro, Kecil, dan Menengah Bintang Malam Pekalongan kesulitan dalam membuat laporan keuangan. Karena perusahaan hanya menggunakan nota yang dibukukan, sehingga informasi yang dihasilkan hanya berupa informasi penjualan dan penerimaan barang saja. Dengan diluncurkannya perangkat-perangkat lunak atau software akuntansi ditujukan untuk meng-input data-data transaksi menjadi data output berbentuk laporan keuangan dengan meminimalisir kesalahan dalam perhitungan maupun penyusunan. Informasi akuntansi atau laporan keuangan dibutuhkan oleh lembaga peminjam modal, untuk mengukur tingkat pengembalian pinjaman. Informasi akuntansi pun diperlukan manajemen perusahaan untuk mengambil keputusan. Oleh karena itu dibutuhkannya laporan keuangan yang baik dan benar.

Media yang digunakan oleh aplikasi akuntansi yaitu komputer, di mana dibutuhkan keahlian pengguna dalam menjalankannya. Teknologi memiliki tiga faktor penting dalam penggunaannya yaitu perangkat keras (hardware), perangkat lunak (software), dan yang paling penting adalah brainware atau pengguna. Keahlian seseorang dalam mengaplikasikan komputer merupakan acuan rasa keyakinan dan kepercaya-dirian individu yang dapat bisa mempengaruhi minat. Jika tingkat kesenangan terhadap komputer tinggi, maka tingkat minat dalam memahami sistem bisnis dapat ikut tinggi (Sudibyanto, 2013). Rasa keyakinan atau kepercaya-dirian dalam menggunakan komputer disebut Computer Self-

* Corresponding author's e-mail: bambangsugihart@gmail.com

http://openjournal.unpam.ac.id/index.php/JABI 
Jurnal Akuntansi Berkelanjutan Indonesia - Vol. 3, No. 1, Jan 2020 - Defillaleti; Sugiharto \& Umiyati

efficacy (CSE). Menurut Sudibyanto (2013), Computer Self-efficacy (CSE) tidak hanya menyangkut skill seseorang, tetapi meliputi judgements mengenai tindakan apa yang dapat dilakukannya untuk menyelesaikan tugas-tugas terkait dengan pengaplikasian komputer dan juga menjadi faktor yang berpengaruh terhadap penggunaan sebuah sistem. Akan tetapi dalam memanfaatkan teknologi informasi diperlukannya kondisi-kondisi yang memfasilitasi atau Facilitating Conditions. Menurut Maharsi (2000), untuk dapat memiliki keahlian dan kemampuan tentang teknologi informasi, maka anggota organisasi perlu mendapatkan tambahan pendidikan dan pelatihan serta pemberian keterampilan-keterampilan yang relevan. Penyusunan laporan keuangan menggunakan aplikasi akuntansi dibutuhkan kondisi-kondisi yang memfasilitasi (Facilitating Conditions), seperti tersedianya pedoman atau buku panduan yang lengkap dan pelatihan khusus mengaplikasikan sistem akuntansi.

Minat pengusaha dalam menerapkan sistem aplikasi akuntansi cenderung sedikit, dikarenakan berbagai alasan seperti terlalu nyaman mencatat transaksi secara manual walaupun seadanya, kurangnya informasi tentang produk-produk software akuntansi sehingga tujuan aplikasi akuntansi untuk membantu dan mempermudah pencatatan transaksi kurang mendapat respon dari pengusaha (Lestari, 2018). Menurut Jogiyanto (2007) dalam Lestari (2018), minat adalah keinginan untuk berperilaku. Minat tidak selalu statis dan minat dapat berubah dengan berjalannya waktu.

Dalam penelitian Debbianita dan Sitorus (2016), Trisnapuri (2016), Rafiqa (2018), dan Salmiah, et.al (2018), menjelaskan tentang Standar Akuntansi Keuangan sebagai faktor yang dapat mempengaruhi penyusunan laporan keuangan suatu perusahaan. Penyusunan laporan keuangan disesuaikan dengan keadaan perkembangan teknologi saat ini, laporan keuangan dapat di susun dengan sistem akuntansi terkomputerisasi atau software akuntansi. Oleh karena itu, penelitian ini ditujukan untuk mengukur minat pengusaha mikro, kecil, dan menengah dalam menyusun laporan keuangan menggunakan software akuntansi.

Penelitian yang dilakukan Lestari (2018) dan Sudibyanto (2013), menunjukan bahwa variabel Computer Self-efficacy (CSE) berpengaruh terhadap minat menggunakan aplikasi akuntansi, berbeda dengan hasil penelitian Mediaty, Pontoh, dan Kartini (2017) di mana Computer Self-efficacy tidak berpengaruh pada minat pemanfaatan teknologi e-office. hal ini berarti bahwa program aplikasi pengguna sistem e-office baik tinggi atau rendah tidak akan berdampak pada minat pemanfaatan teknologi e-office. Penelitian yang dilakukan Bendi dan Andayani (2013), Rohmadi et al. (2017) menunjukan bahwa variabel Facilitating Condition berpengaruh terhadap minat. Tetapi penelitian dari Mediyanto dan Mahendra (2017), serta Kurniawan et al. (2016) menunjukan bahwa variabel Facilitating Conditions tidak berpengaruh terhadap minat. Penjelasan ini menunjukan bahwa terdapat adanya perbedaan hasil penelitian dari variabel Computer Self-efficacy (CSE) dan Facilitating Conditions, maka penelitian ini ingin memastikan bahwa Facilitating Conditions dapat berpengaruh positif terhadap minat menggunakan aplikasi akuntansi.

* Corresponding author's e-mail: bambangsugihart@gmail.com

http://openjournal.unpam.ac.id/index.php/JABI 
Jurnal Akuntansi Berkelanjutan Indonesia - Vol. 3, No. 1, Jan 2020 - Defillaleti;

Sugiharto \& Umiyati

Berdasarkan paparan di atas, penelitian ini dimaksudkan untuk meneliti ada atau tidaknya pengaruh pengetahuan usaha mikro, kecil, dan menengah tentang Standar Akuntansi Keuangan Entitas Mikro Kecil dan Menengah (SAK EMKM) terhadap minat menggunakan aplikasi akuntansi dalam membantu menyusun laporan keuangan perusahaan. Lalu, meneliti pengaruh Computer Self-efficacy, dan Facilitating Conditions terhadap Minat Menggunakan Aplikasi Akuntansi.

\section{KERANGKA TEORITIS DAN PENGEMBANGAN HIPOTESIS}

\section{Social Cognitive Theory (SCT)}

Bandura (1989) menggambarkan konsep teori kognitif sosial, sebagai fungsi psikologis yang menyebabkan segitiga timbal balik. Dalam model yang dijelaskan dalam perilaku itu, faktor-faktor kognitif dan pribadi lainnya, dan lingkungan saling mempengaruhi. Hubungan timbal balik antara orang/kognitif dan perilaku mencerminkan interaksi antara pikiran dan mempengaruhi perilaku mereka. Apa yang orang pikirkan, yakini, dan cicipi, mempengaruhi cara mereka bersikap selfefficacy yang berasal dari penguasaan enaktif parsial selama pengobatan memperkirakan kinerja pada tugas-tugas yang membuat stress yang belum pernah dilakukan individu sebelumnya.

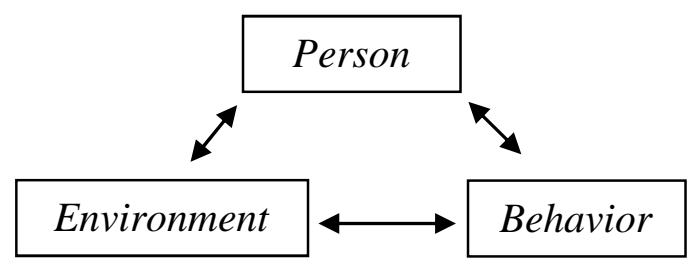

Gambar 1:

Triadic Reciprocality atau Reciprocal Determinism Sumber : Compeau dan Higgins (1995)

Gambar di atas menjelaskan tentang hubungan timbal balik antara individu, lingkungan, dan perilaku. Di mana pengaruh lingkungan seperti tekanan sosial atau karakteristik situasional yang unik, kognitif, dan faktor personal lainnya termasuk kepribadian serta karakteristik demografis, dan perilaku ditentukan secara timbal balik (Compeau \& Higgins, 1995). Berdasarkan Triadic Reciprocality ini terdapat tiga faktor saling mempengaruhi terdiri dari faktor personal (bentuk kognisi, afektif dan peristiwa biologis), pengaruh lingkungan, dan faktor tingkah laku. Pada tahun 1995, Compeau dan Higgins melakukan pengembangan teori Social Cognitive Theory terhadap teknologi yaitu komputer, pengembangan ini dimaksudkan untuk mengukur kemampuan dan keyakinan diri seseorang dalam pemanfaatan komputer.

Menurut Compeau dan Higgins terdapat 5 inti dari teori sosial kognitif ini, yaitu yang digambarkan sebagai berikut:

1. Ekspektasi Hasil - Kinerja (Outcome Expectations-Performance)

* Corresponding author's e-mail: bambangsugihart@gmail.com

http://openjournal.unpam.ac.id/index.php/JABI 
Jurnal Akuntansi Berkelanjutan Indonesia - Vol. 3, No. 1, Jan 2020 - Defillaleti;

Sugiharto \& Umiyati

Ekspektasi hasil, yang didefinisikan sebagai konsekuensi yang dirasakan kemungkinan menggunakan komputer, memiliki dua dimensi. Hasil yang terkait dengan kinerja adalah yang terkait dengan peningkatan kinerja pekerjaan (efisiensi dan efektivitas) yang terkait dengan penggunaan komputer.

2. Ekspektasi Hasil - Pribadi (Outcome Expectations-Personal)

Berhubungan dengan ekspektasi perubahan dalam pandangan atau status atau ekspektasi pada penghargaan, seperti promosi, kenaikan gaji, atau pujian.

3. Efikasi Diri (Self-efficacy)

Keputusan kemampuan seseorang untuk menggunakan teknologi untuk menyelesaikan pekerjaan atau tugas tertentu. Dalam konteks penggunaan komputer, Compeau dan Higgins (1995) mengartikan computer self efficacy sebagai persepsi seseorang tentang kemampuannya untuk menggunakan komputer dalam penyelesaian tugas (misalnya mengunakan paket perangkat lunak untuk analisis data).

4. Pengaruh (Affect)

Pengaruh (Affect) dan kecemasan (Anxiety) mewakili tanggapan afektif individu terhadap penggunaan komputer. Pengaruh mempengaruhi sisi positif - kenikmatan yang diperoleh seseorang dari menggunakan komputer.

5. Kecemasan (Anxiety)

Kecemasan mewakili sisi negatif - perasaan ketakutan atau kecemasan yang dialami seseorang ketika menggunakan komputer. Dengan kata lain kecemasan adalah suatu perasaan yang membangkitkan reaksi cemas atau emosional saat harus melakukan suatu perilaku sehingga sebisa mungkin untuk menghindarinya

6. Penggunaan (usage)

Penggunaan mewakili tingkat penggunaan komputer di tempat kerja dan di rumah.

Berdasarkan uraian diatas, menunjukan bahwa Computer Self-efficacy mencerminkan kemampuan individu dalam menghadapi kemudahan atau kesulitan dirasa, yang akan mempengaruhi perilaku yang berhubungan dengan komputer misalnya minat menggunakan aplikasi akuntansi.

\section{Theory of Planned Behavior (TPB)}

Theory Planned of Behavior (TPB) adalah pengembangan lebih lanjut dari Theory of Reasoned Action (TRA), di mana menambahkan suatu konstruk kontrol perilaku persepsi-an (perceived behavioral control). Theory of Reasoned Action (TRA) dikembangkan oleh Icek Ajzen dan Martin Fishbein (1980) bahwa perilaku dilakukan karena individual mempunyai minat atau keinginan untuk melakukannya. Theory of Reasoned Action (TRA) adalah suatu teori yang berhubungan dengan sikap dan perilaku individu dalam melaksanakan kegiatan (Jogiyanto, 2007). Menurut Ajzen (2012), Theory of Reasoned Action (TRA) memiliki beberapa konstruk sebagai berikut:

1. The cognitive foundation of attitudes;

2. Historical and theoretical context;

* Corresponding author's e-mail: bambangsugihart@gmail.com

http://openjournal.unpam.ac.id/index.php/JABI 
Jurnal Akuntansi Berkelanjutan Indonesia - Vol. 3, No. 1, Jan 2020 - Defillaleti;

Sugiharto \& Umiyati

3. Perceived behavioral control;

4. Predicting intentions and behavior;

5. Accessibility of beliefs;

6. Predicting and explaining intentions.

Theory Planned of Behavior (TPB) merupakan sebuah teori yang dapat menilai perilaku seseorang berdasarkan faktor-faktor dalam Theory Planned of Behavior. Dalam Ajzen (1985), Theory Planned of Behavior (TPB) mendefinisikan minat (dan konstruk teoretis lainnya) dalam hal mencoba melakukan perilaku yang diberikan daripada dalam kaitannya dengan kinerja aktual. Ketika individu melakukan kegiatan berbagi pengetahuan hal ini merupakan sebuah perilaku, sebagaimana didalam Theory Planned of Behavior (TPB) perilaku dipengaruhi niat, sedangkan niat dipengaruhi oleh beberapa faktor yaitu sikap terhadap perilaku (attitude toward behavior), norma subjektif (subjective norm), dan kontrol perilaku yang dipersepsikan (perceived behavior control) (Ajzen, 1991). Dalam Ajzen (1991) menggambarkan kemungkinan adanya efek timbal balik antar variabel sebagai berikut.

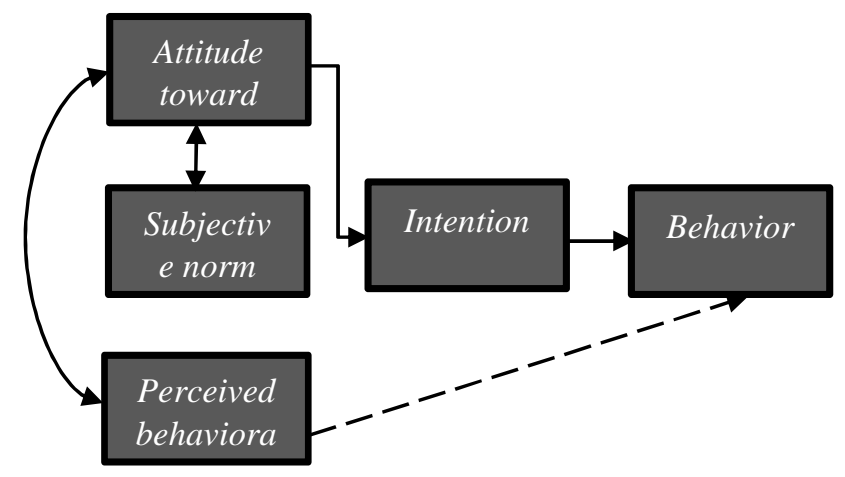

Gambar 2:

Timbal balik antar variabel Theory Planned of Behavior (TPB) Sumber: Ajzen (1991)

Gambar 2 menunjukan bahwa Attitude toward the behavior mengacu pada sejauh mana seseorang memiliki evaluasi atau penilaian yang menguntungkan maupun tidak menguntungkan dari perilaku yang bersangkutan. Subjective Norm yaitu faktor sosial yang mengacu pada tekanan sosial yang dirasakan untuk melakukan atau tidak melakukan suatu perilaku. Perceived behavioral control mengacu pada kemudahan atau kesulitan yang dirasakan dalam melakukan suatu perilaku dan dapat dianggap mencerminkan pengalaman sebelumnya serta penghalang dan hambatan yang diantisipasi. Dalam hal ini, variabel pengetahuan Standar Akuntansi Keuangan Entitas Mikro, Kecil, dan Menengah (SAK EMKM) termasuk dalam bagian Perceived behavioral control karena mencerminkan kemampuan individu dalam menghadapi kemudahan atau kesulitan dirasa, yang akan mempengaruhi minat.

* Corresponding author's e-mail: bambangsugihart@gmail.com

http://openjournal.unpam.ac.id/index.php/JABI 
Jurnal Akuntansi Berkelanjutan Indonesia - Vol. 3, No. 1, Jan 2020 - Defillaleti;

Sugiharto \& Umiyati

\section{Unified Theory of Acceptance and Use of Technology 2}

Unified Theory of Acceptance and Use of Technology (UTAUT) merupakan teori yang dikembangkan oleh Viswanath Venkatesh, James Y. L. Thong, dan Xin $\mathrm{Xu}$. Unified Theory of Acceptance and Use of Technology (UTAUT) memiliki empat konstruk utama yang mempengaruhi minat perilaku untuk menggunakan teknologi dan/atau penggunaan teknologi, yaitu:

1. Harapan kinerja (Performance Expectancy) adalah sejauh mana individu percaya bahwa menggunakan sistem akan membantu dia untuk mencapai keuntungan dalam kinerja pekerjaan.

2. Harapan Usaha (Efort expectancy) adalah tingkat kemudahan terkait dengan penggunaan sistem.

3. Pengaruh sosial (Social Influence) adalah tingkat di mana individu merasakan bahwa penting percaya padanya atau dia harus menggunakan sistem baru.

4. Kondisi yang memfasilitasi (Facilitating Conditions) adalah sejauh mana seorang individu percaya bahwa infrastruktur organisasi dan teknis hadir untuk mendukung penggunaan sistem. (Venkatesh, Morris, Davis, \& Davis, 2003)

Dalam Unified Theory of Acceptance and Use of Technology 2 (UTAUT 2) terdapat tambahan konstruk-konstruk baru sebagai berikut:

1. Hedonic Motivation didefinisikan sebagai kegembiraan atau kesenangan yang diperoleh dari penggunaan teknologi, dan telah terbukti memainkan peran penting dalam menentukan penerimaan dan penggunaan teknologi.

2. Price Value didefinisikan ketika manfaat menggunakan teknologi dianggap lebih besar daripada biaya moneter dan nilai harga tersebut memiliki dampak positif pada niat.

3. Experience and Habit didefinisikan sebagai sejauh mana orang cenderung untuk melakukan perilaku otomatis karena pembelajaran. (Venkatesh, Thong, \& XinXu, 2012).

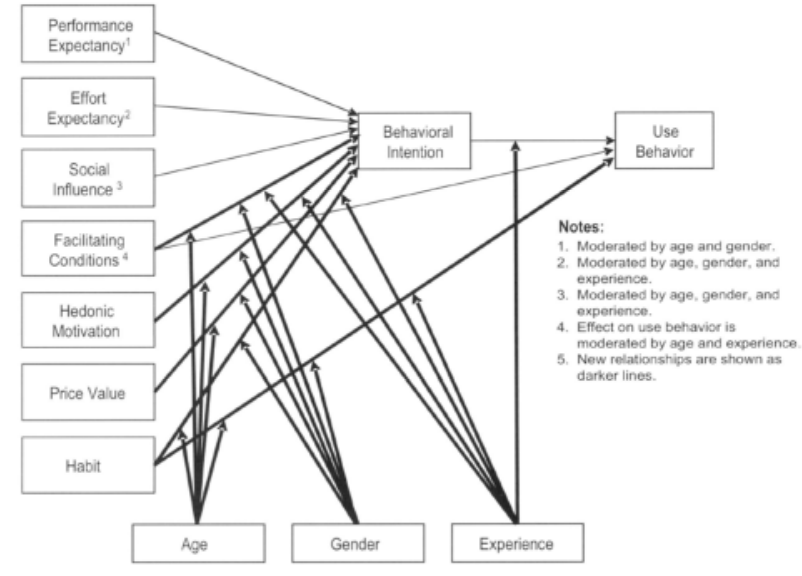

Gambar 3:

Unified Theory of Acceptance and Use of Technology 2 (UTAUT 2)

Sumber: Venkatesh, Thong, dan Xin Xu (2012)

* Corresponding author's e-mail: bambangsugihart@gmail.com

http://openjournal.unpam.ac.id/index.php/JABI 
Jurnal Akuntansi Berkelanjutan Indonesia - Vol. 3, No. 1, Jan 2020 - Defillaleti;

Sugiharto \& Umiyati

Gambar 3 menunjukan bahwa adanya hubungan antara Facilitating Conditions dengan minat. Berdasarkan gambar di atas, Facilitating Conditions dapat mempengaruhi minat dengan menggunakan Unified Theory of Acceptance and Use of Technology 2 (UTAUT 2) sebagai teori yang menjembatani antara variabel bebas dan variabel terikat.

\section{Standar Akuntansi Keuangan Entitas Mikro Kecil dan Menengah}

Pada tahun 2016, Standar Akuntansi Keuangan Entitas Mikro Kecil dan Menengah (SAK EMKM) disahkan oleh Dewan Standar Akuntan Keuangan Ikatan Akuntan Indonesia (DSAK IAI), lalu diberlakukan secara efektif pada tanggal 1 Januari 2018 sebagai upaya mendukung kemajuan perekonomian negara. Dewan Standar Akuntan Keuangan Ikatan Akuntan Indonesia (DSAK IAI) adalah badan otorisasi yang memiliki tanggung jawab utama dalam mengembangkan standar akuntansi di Indonesia (Warren, et al., 2017).

Standar Akuntansi Keuangan Entitas Mikro Kecil dan Menengah (SAK EMKM) digunakan oleh entitas yang tidak atau belum memenuhi persyaratan, definisi, dan kriteria yang diatur dalam Standar Akuntansi Keuangan Entitas Tanpa Akuntabilitas Publik (SAK ETAP). Standar Akuntansi Keuangan Entitas Mikro Kecil dan Menengah (SAK EMKM) berkaitan dengan laporan keuangan perusahaan. Seperti yang tertera dalam Standar Akuntansi Keuangan Entitas Mikro Kecil dan Menengah (SAK EMKM) di mana tujuan dari laporan keuangan adalah untuk menyediakan informasi posisi keungan dan kinerja keuangan suatu entitas yang bermanfaat bagi sejumlah besar pengguna dalam pengambilan keputusan ekonomi oleh siapapun yang tidak dalam posisi dapat meminta laporan keuangan khusus untuk memenuhi kebutuhan informasi tersebut. Informasi posisi keuangan perusahaan terdapat beberapa unsur, yaitu:

1. Aset merupakan sumber daya yang dikuasai oleh entitas sebagai akibat dari peristiwa masa lalu dan dari mana manfaat ekonomi di masa depan diharapkan akan diperoleh oleh entitas.

2. Liabilitas merupakan kewajiban saat ini entitas yang timbul dari peristiwa masa lalu, yang penyelesaiannya mengakibatkan arus keluar dari sumber daya entitas yang mengandung manfaat ekonomi.

3. Ekuitas merupakan hak residual atas aset entitas setelah dikurang seluruh liabilitasnya.

Dalam Peryataan Standar Akuntansi Keuangan (PSAK) 1 tentang penyajian laporan keuangan, laporan keuangan memiliki beberapa komponen yaitu laporan laba rugi, laporan ekuitas pemilik, laporan posisi keuangan, laporan arus kas, dan catatan atas laporan keuangan. Seperti yang ditulis dalam Standar Akuntansi Keuangan Entitas Mikro Kecil dan Menengah (SAK EMKM) bab 3, Penyajian laporan keuangan harus disusun secara jujur atas pengaruh transaksi, peristiwa, dan kondisi lainnya. Sehingga penyajian wajar laporan keuangan sebagai berikut:

1. Relevan yaitu informasi dapat digunakan oleh pengguna untuk proses pengambilan keputusan.

* Corresponding author's e-mail: bambangsugihart@gmail.com

http://openjournal.unpam.ac.id/index.php/JABI 
Jurnal Akuntansi Berkelanjutan Indonesia - Vol. 3, No. 1, Jan 2020 - Defillaleti;

Sugiharto \& Umiyati

2. Representasi tepat yaitu informasi disajikan secara tepat atau secara apa yang seharusnya disajikan dan bebas dari kesalahan material dan bias.

3. Keterbandingan yaitu informasi dalam laporan keuangan entitas dapat dibandingkan antar periode untuk mengidentifikasi kecenderungan posisi dan kinerja keuangan. Informasi dalam laporan keuangan entitas juga dapat dibandingkan antar entitas untuk mengevaluasi posisi dan kinerja keuangan.

4. Keterpahaman yaitu informasi yang disajikan dapat dengan mudah dipahami oleh pengguna.

\section{Hubungan Pengetahuan Standar Akuntansi Keuangan Entitas Mikro Kecil Dan Menengah (SAK EMKM) terhadap minat menggunakan aplikasi akuntansi}

Standar Akuntansi Keuangan Entitas Mikro Kecil Dan Menengah (SAK EMKM) telah diberlakukan secara efektif pada awal tahun 2018, dengan persyaratan yang lebih sederhana di banding Standar Akuntansi Keuangan Entitas Tanpa Akuntan Publik (SAK ETAP). Standar Akuntansi Keuangan Entitas Mikro Kecil Dan Menengah (SAK EMKM) disusun untuk mendorong dan memfasilitasi usaha mikro, kecil, dan menengah dalam menyusun laporan keuangan. Sehingga pengetahuan pengusaha tentang penyajian laporan keuangan sesuai Standar Akuntansi Keuangan yang berlaku harus tinggi agar mencegah terjadinya kesalahan dalam mencatat (misstatement). Dalam penelitian Nurfadilah (2018), menunjukan bahwa ada 8 home industri kripik tempe yang sudah memahami SAK ETAP. Dan hanya ada 1 home industri yang tidak memahami tentang SAK ETAP.

Diberlakukannya Standar Akuntansi Keuangan Entitas Mikro Kecil Dan Menengah (SAK EMKM) ditujukan untuk usaha yang belum mampu memenuhi persyaratan akuntansi dalam Standar Akuntansi Keuangan Entitas Tanpa Akuntan Publik (SAK ETAP). Fungsi dari aplikasi akuntansi itu sendiri untuk membantu dan memudahkan pelaku usaha dalam penyusunan laporan keuangan perusahaan dengan kecil kemungkinan terjadi misstatement. Akan tetapi, apakah Usaha Mikro, Kecil, dan Menengah lebih memilih menyajikan laporan keuangan secara manual atau berminat untuk menggunakan aplikasi sesuai standar yang berlaku. Oleh sebab itu, adakah pengaruh pengetahuan Standar Akuntansi Keuangan Entitas Mikro Kecil Dan Menengah (SAK EMKM) terhadap minat menggunakan aplikasi akuntansi untuk penyusunan laporan keuangan perusahaan.

$\mathrm{H}_{1}=$ Pengetahuan Standar Akuntansi Keuangan Entitas Mikro Kecil Dan Menengah (SAK EMKM) (X1) berpengaruh secara positif terhadap minat menggunakan aplikasi akuntansi (Y)

\section{Hubungan Computer Self-efficacy terhadap minat menggunakan aplikasi akuntansi}

Di era kemajuan teknologi, penggunaan teknologi informasi bukan lagi hal yang tabu, karena saat ini teknologi sangat dibutuhkan manusia. Di mana individu maupun kelompok/organisasi membutuhkan informasi yang mudah, akurat, dan cepat didapat dengan memanfaatkan sistem teknologi berbasis komputerisasi. Teknologi dapat membantu dan mempermudah pengguna dalam menyelesaikan

* Corresponding author's e-mail: bambangsugihart@gmail.com

http://openjournal.unpam.ac.id/index.php/JABI 
Jurnal Akuntansi Berkelanjutan Indonesia - Vol. 3, No. 1, Jan 2020 - Defillaleti;

Sugiharto \& Umiyati

tugas-tugasnya, termasuk penyusunan laporan keuangan perusahaan. Penelitian yang dilakukan Lestari (2018), dan Sudibyanto (2013), menunjukan bahwa variabel Computer Self-efficacy (CSE) berpengaruh terhadap minat menggunakan aplikasi akuntansi.

$\mathrm{H}_{2}=$ Computer Self-efficacy (X2) berpengaruh secara positif terhadap minat menggunakan aplikasi akuntansi (Y)

\section{Hubungan Facilitating Conditions terhadap minat menggunakan aplikasi akuntansi}

Teknologi informasi memiliki tiga perangkat yaitu perangkat keras (hardware), perangkat lunak (software), dan yang terpenting adalah pengguna (brainware). Aplikasi akuntansi dominan menggunakan komputer, saat menjalankan perangkat komputer atau perangkat lunak aplikasi keahlian pengguna di uji. Keahlian timbul dengan adanya pelatihan, panduan dan bimbingan khusus, sehingga pengguna mampu mengaplikasikan perangkat lunak akuntansi. Hasil uji hipotesis dari penelitian Bendi dan Andayani (2013), Rohmadi et al. (2017) menunjukan bahwa variabel Facilitating Conditions berpengaruh terhadap minat.

$\mathrm{H}_{3}=$ Facilitating Conditions (X3) berpengaruh positif terhadap minat menggunakan aplikasi akuntansi (Y)

Hubungan Pengetahuan Standar Akuntansi Keuangan Entitas Mikro Kecil Dan Menengah (SAK EMKM), Computer Self-efficacy (CSE), dan Facilitating Conditions berpengaruh positif terhadap minat menggunakan aplikasi akuntansi

Standar Akuntansi Keuangan Entitas Mikro Kecil dan Menengah (SAK EMKM) merupakan dasar pembentukan laporan keuangan untuk usaha mikro, kecil, dan menengah. Standar Akuntansi Keuangan Entitas Mikro Kecil dan Menengah (SAK EMKM) disusun untuk mendorong dan memfasilitasi usaha mikro, kecil, dan menengah dalam menyusun laporan keuangan. Dengan berkembangnya teknologi saat ini menjadikan banyak bermunculan aplikasiaplikasi akuntansi terkomputerisasi, yang dimaksudkan untuk memudahkan penggunanya dalam mencatat dan menyusun laporan keuangan minim kesalahan. Maka dibutuhkannya suatu kemampuan dan keyakinan diri dalam mengoperasikan suatu teknologi yang disebut Computer Self-efficacy (CSE). Dalam pengaplikasian suatu software akuntansi dibutuhkan panduan dan pelatihan dari pihak pembuat software tersebut atau mungkin dituntun saat pengoperasian sofware akuntansi oleh individu yang cukup ahli, beberapa hal ini termasuk dalam variabel Facilitating Conditions.

Dalam hipotesis gabungan ini, adakah pengaruh antara pengetahuan Standar Akuntansi Keuangan Entitas Mikro Kecil Dan Menengah (SAK EMKM), Computer Self-efficacy (CSE), dan Facilitating Conditions terhadap minat menggunakan aplikasi akuntansi pada usaha mikro, kecil dan menengah.

$\mathrm{H}_{4}=$ Pengetahuan Standar Akuntansi Keuangan Entitas Mikro Kecil Dan Menengah (SAK EMKM), Computer Self-efficacy (CSE), dan Facilitating

* Corresponding author's e-mail: bambangsugihart@gmail.com

http://openjournal.unpam.ac.id/index.php/JABI 
Jurnal Akuntansi Berkelanjutan Indonesia - Vol. 3, No. 1, Jan 2020 - Defillaleti;

Sugiharto \& Umiyati

Conditions berpengaruh positif terhadap minat menggunakan aplikasi akuntansi (Y)

\section{METODE RISET}

\section{Desain Penelitian}

Penelitian ini termasuk dalam penelitian kuantitatif dengan metode survei. Menurut Effendi dan Tukiran (2014) dalam Andryanto (2016), penelitian survei adalah penelitian yang mengambil sampel dari satu populasi dan menggunakan kuesioner sebagai alat pengumpulan data yang pokok. Dalam penelitian ini metode survei yang dilakukan berupa kuesioner atau angket (self-administered questionnaire) yang dibagikan kepada responden untuk diisi, baik itu melalui kertas maupun melalui perangkat komunikasi canggih lainnya.

\section{Tempat dan Waktu Penelitian}

Penelitian ini dilakukan pada tanggal 1 Maret sampai dengan $10 \mathrm{Mei}$. Penyebaran kuesioner dilakukan dengan cara mengunjungi langsung kios-kios maupun melalui jejaring sosial kepada pengusaha yang termasuk dalam kategori usaha mikro, kecil, dan menengah di Kabupaten Subang.

\section{Populasi dan Sampel}

Populasi untuk penelitian ini ialah unit usaha mikro, kecil, dan menengah di Kabupaten Subang. Penelitian ini menggunakan data primer, karena sampel diperoleh secara langsung kepada 100 responden (batas minimum) yaitu unit usaha mikro, kecil, dan menengah di Kabupaten Subang. Metode yang digunakan untuk menentukan jumlah sampel di penelitian ini adalah rumus Slovin, sebagai berikut:

$$
\begin{gathered}
=\frac{29236}{1+} \\
=\frac{29236(0,10)}{1+29236} \\
=\frac{29236}{1+29236(0,01)} \\
=\frac{29236}{293,36} \\
=99,6591219
\end{gathered}
$$

$n=$ jumlah sampel, setelah perhitungan diketahui sebesar 99,66 dibulatkan menjadi 100.

$N=$ jumlah populasi sebesar 29.236 unit usaha mikro, kecil, dan menengah

$e^{2}=$ batas toleransi kesalahan (error tolerance) yaitu $(0,10) 2=0,01$

Data primer (primary data) mengacu pada informasi yang diperoleh langsung (dari tangan pertama) oleh peneliti terkait dengan variabel ketertarikan untuk tujuan tertentu dari studi (Sekaran dan Bougie, 2017).

* Corresponding author's e-mail: bambangsugihart@gmail.com http://openjournal.unpam.ac.id/index.php/JABI 
Jurnal Akuntansi Berkelanjutan Indonesia - Vol. 3, No. 1, Jan 2020 - Defillaleti;

Sugiharto \& Umiyati

\section{Teknik Pengambilan Sampel}

Teknik pengambilan sampling yang digunakan pada penelitian ini adalah Sampling Insidental. Sampling Insidental merupakan teknik penentuan sampel berdasarkan kebetulan, yaitu siapa saja yang tidak sengaja bertemu dengan peneliti dapat digunakan sebagai sampel, bila orang tersebut cocok sebagai sumber data.

\section{Instrumen Penelitian}

Instrumen penelitian ini adalah kuesioner yang disusun berdasarkan indikator-indikator setiap variabel, sebagai berikut:

Tabel 1:Instrumen Penelitian

\begin{tabular}{|c|c|c|c|}
\hline 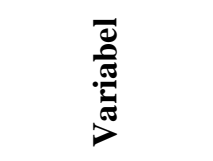 & Indikator & No Item & 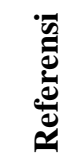 \\
\hline 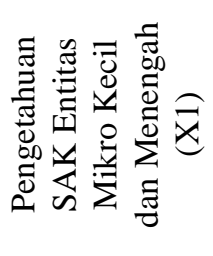 & $\begin{array}{c}\text { Pencatatan Akuntansi. } \\
\text { Standar Akuntansi } \\
\text { Keuangan Entitas } \\
\text { Mikro Kecil dan } \\
\text { Menengah }\end{array}$ & $\begin{array}{l}1,2,3,4,5,6,7,8,9,10 \\
11,12,13,14,15,16,17\end{array}$ & 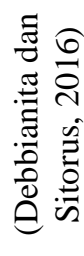 \\
\hline 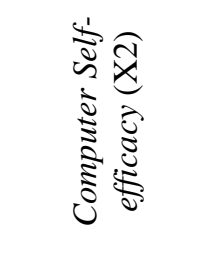 & $\begin{array}{l}\text { Kapabilitas komputer, } \\
\text { Komputasi yang baik, } \\
\text { Mampu menjalankan } \\
\text { paket-paket software } \\
\text { yang berbeda. }\end{array}$ & $\begin{array}{l}18,19,20,21,22,23,24 \\
25,26,27,28,29,30 .\end{array}$ & 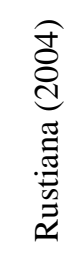 \\
\hline 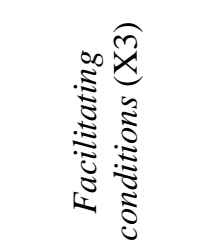 & $\begin{array}{c}\text { Panduan } \\
\text { Pelatihan } \\
\text { Orang yang membantu }\end{array}$ & $31,32,33,34,35$. & 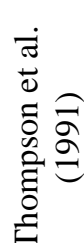 \\
\hline 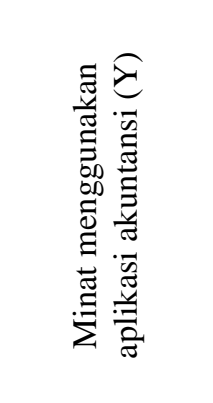 & $\begin{array}{c}\text { Keinginan untuk } \\
\text { menggunakan aplikasi } \\
\text { akuntansi, } \\
\text { Selalu mencoba } \\
\text { menggunakan aplikasi } \\
\text { akuntansi, } \\
\text { Berlanjut menggunakan } \\
\text { aplikasi akuntansi } \\
\text { dimasa yang akan } \\
\text { datang. }\end{array}$ & $36,37,38$. & 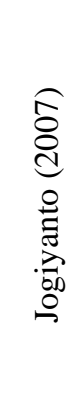 \\
\hline
\end{tabular}

Sumber: Olahan berbagai jurnal

* Corresponding author's e-mail: bambangsugihart@gmail.com

http://openjournal.unpam.ac.id/index.php/JABI 
Jurnal Akuntansi Berkelanjutan Indonesia - Vol. 3, No. 1, Jan 2020 - Defillaleti;

Sugiharto \& Umiyati

\section{Uji Intrumen Penelitian}

\section{Uji Validitas}

Uji validitas digunakan untuk mengukur sah atau tidaknya sebuah kuesioner. Jika pertanyaan dalam kuesioner dapat mengungkapkan sesuatu terkait data yang diteliti, maka kuesioner tersebut dapat dikatakan sah atau valid.

\section{Uji Reliabilitas}

Reliabilitas adalah alat untuk mengukur suatu kuesioner yang merupakan indikator dari variabel atau kontruk (Umiyati dan Nurmalasari, 2016). Menurut Ghozali (2013), Tingkat realibilitas suatu konstruk/variabel dapat dilihat dari hasil statistik Cronbach Alpha $(\alpha)$ suatu variabel dikatakan reliabel jika memberikan nilai Cronbach Alpha $>0,60$.

\section{Teknik Analisis Data \\ Analisis Statistik Deskriptif}

Pada dasarnya statistik deskriptif merupakan proses mengidentifikasi kecenderungan variabel-variabel penelitian melalui jumlah nilai total dari setiap responden (Sugiyono, 2018).

\section{Analisis Kuantitatif}

Dalam analisis kuantitatif terdapat beberapa pengujian yaitu uji asumsi klasik, regresi berganda dan uji hipotesis yang akan dijelaskan seperti dibawah ini:

a. Uji asumsi klasik

Dalam penelitian ini menggunakan uji normalitas, uji multikolinearitas dan uji heteroskedastisitas dan homokedastisitas.

b. Analisis Regresi Linier Berganda

Menurut Lestari (2018), persamaan regresi berganda yaitu mengukur kekuatan hubungan antara dua variabel atau lebih, dan untuk menunjukan arah hubungan antara variabel bebas dan variabel terikat. Persamaan regresi liner berganda dalam penelitian ini adalah sebagai berikut:

$$
\mathrm{Y}=\alpha+\mathrm{b}_{1} \mathrm{X}_{1}+\mathrm{b}_{2} \mathrm{X}_{2}+\mathrm{b}_{3} \mathrm{X}_{3}+\mathrm{e}
$$

Keterangan:

$\mathrm{Y}=$ Minat menggunakan aplikasi akuntansi

$\alpha \quad=$ Kontanta

$b_{1} \ldots b_{5}=$ Koefisien

$\mathrm{X}_{1} \quad=$ Pengetahuan SAK EMKM

$\mathrm{X}_{2} \quad=$ Computer Self-efficacy

$\mathrm{X}_{3} \quad=$ Facilitating Conditions

c. Uji Hipotesis

Penelitian ini menggunakan tiga pengujian hipotesis yaitu koefisien determinan $\left(\mathrm{R}^{2}\right)$, uji t-statistik (Parsial), dan uji simultan (Uji F). 
Jurnal Akuntansi Berkelanjutan Indonesia - Vol. 3, No. 1, Jan 2020 - Defillaleti;

Sugiharto \& Umiyati

\section{ANALISIS DATA DAN PEMBAHASAN}

\section{Hasil Uji Instrumen Penelitian \\ Uji Validitas}

Variabel pengetahuan SAK Entitas Mikro Kecil dan Menengah (X1) memiliki 17 pertanyaan berdasarkan indikator didalamnya. Dimana $r_{\text {tabel }}$ adalah 0.13708. Maka seluruh pertanyaan dalam variabel pengetahuan SAK Entitas Mikro Kecil dan Menengah dapat dinyatakan valid karena $r_{\text {hitung }}>r_{\text {tabel. }}$

Pada variabel Computer Self-efficacy (X2) memiliki 13 pertanyaan berdasarkan indikator didalamnya. Nilai $r_{\text {tabel }} 0.13708$. Seluruh pertanyaan dalam variabel Computer Self-efficacy dapat dinyatakan valid, karena $\mathrm{r}_{\text {hitung }}>\mathrm{r}_{\text {tabel. }}$.

Variabel Facilitating conditions (X3) memiliki 5 pertanyaan berdasarkan indikator didalamnya. Seluruh pertanyaan dalam variabel Facilitating conditions dapat dinyatakan valid, karena $r_{\text {hitung }}>r_{\text {tabel. }}$.

Variabel minat menggunakan aplikasi akuntansi (Y) memiliki 3 pertanyaan berdasarkan indikator didalamnya. Seluruh pertanyaan dalam variabel minat menggunakan aplikasi akuntansi dapat dinyatakan valid, karena $r_{\text {hitung }}>r_{\text {tabel }}$

\section{Uji Reliabilitas}

\section{Tabel 2: Uji Reliabilitas}

\begin{tabular}{clcc}
\hline No. & Variabel & Cronbach's Alpha & Keterangan \\
\hline 1 & Pengetahuan SAK Entitas Mikro Kecil & 0,913 & Reliabel \\
2 & Computer Self-efficacy (X2) & 0,929 & Reliabel \\
3 & Facilitating conditions (X3) & 0,800 & Reliabel \\
4 & Minat menggunakan aplikasi akuntansi & 0,822 & Reliabel \\
\hline
\end{tabular}

Sumber : Hasil pengolahan data dengan SPSS versi 22, 2019

Berdasarkan Tabel 2 dapat dilihat bahwa hasil dari uji reliabilitas menunjukan seluruh nilai setiap variabel lebih besar dari 0,60 sehingga lulus uji atau disebut data reliabel.

\section{Hasil Uji Asumsi Klasik Uji Normalitas}

Penelitian ini menggunakan Uji One Sample Kolmogorov-Smirnov, di mana nilai yang didapat sebesar 0,039 dan signifikan pada 0,200 lebih besar dari 0,01 maka data terdistribusi normal.

\section{Uji Multikolinearitas}

Hasil uji Multikolinearitas didapat nilai Tolarance dari variabel pengetahuan SAK Entitas Mikro Kecil dan Menengah (X1) sebesar 0,786, Computer Selfefficacy (X2) sebesar 0,773, dan Facilitating conditions (X3) sebesar 0,820 lebih besar dari 0,10 dan VIF lebih kecil dari 10. Maka dapat disimpulkan bahwa tidak ada multikolinearitas antar-variabel bebas. 
Jurnal Akuntansi Berkelanjutan Indonesia - Vol. 3, No. 1, Jan 2020 - Defillaleti;

Sugiharto \& Umiyati

\section{Uji Heteroskedastisitas}

Hasil uji Heteroskedastisitas mendapat nilai signifikan per variabel bebas lebih besar dari 0,05 ( $\mathrm{Sig}>0,05$ ), oleh karena itu variabel pengetahuan SAK Entitas Mikro Kecil dan Menengah (X1) sebesar 0,810, Computer Self-efficacy (X2) sebesar 0,325, dan Facilitating conditions (X3) sebesar 0,706 sehingga dinyatakan tidak terjadi gejala heteroskedastisitas.

\section{Uji Regresi Berganda}

Hasil uji regresi berganda sebagai berikut:

Tabel 3: Hasil Analisis Regresi

\section{Coefisien $^{\mathrm{a}}$}

\begin{tabular}{crrr}
\hline Model & $\begin{array}{c}\text { Unstandardized } \\
\text { Coefficients } \\
\text { B }\end{array}$ & t & Sig. \\
\hline (Constant) & -0.717 & -0.663 & 0.508 \\
X1 & 0.064 & 4.057 & 0.000 \\
X2 & 0.081 & 5.583 & 0.000 \\
X3 & 0.259 & 6.115 & 0.000 \\
\hline
\end{tabular}

Sumber : Hasil pengolahan data dengan SPSS versi 22

Sesuai dengan tabel di atas maka dapat dirumuskan persamaan regresi berganda,

$$
Y=-0,717+0.064 X_{1}+0,081 X_{2}+0,259 X_{3}
$$

Berdasarkan persamaan regresi berganda di atas menimbulkan beberapa makna yaitu:

1. Nilai konstanta berada di angka $-0,717$ berarti bahwa rata-rata variabel dependen yaitu minat menggunakan aplikasi akuntansi akan mengalami penurunan sebesar 0,717 jika seluruh variabel independen mendapat nilai sama dengan nol.

2. Nilai kofisien regresi variabel pengetahuan SAK Entitas Mikro Kecil dan Menengah (X1) yaitu 0.064. Jika terjadi kenaikan pada variabel ini sebesar satu satuan, maka akan meningkatkan variabel minat menggunakan aplikasi akuntansi sebanyak 0,064 .

3. Nilai koefisien regresi variabel Computer Self-efficacy (X2) yaitu 0,081. Jika terjadi kenaikan pada variabel ini sebesar satu satuan, maka akan meningkatkan variabel minat menggunakan aplikasi akuntansi sebanyak 0,081 .

4. Nilai koefisien regresi variabel Facilitating conditions (X3) yaitu 0,259. Jika terjadi kenaikan pada variabel ini sebesar satu satuan, maka akan meningkatkan variabel minat menggunakan aplikasi akuntansi sebanyak 0,259 . 
Jurnal Akuntansi Berkelanjutan Indonesia - Vol. 3, No. 1, Jan 2020 - Defillaleti;

Sugiharto \& Umiyati

\section{Hasil Uji Hipotesis}

\section{Koefisien Determinan $\left(\mathbf{R}^{2}\right)$}

\section{Tabel 4: Hasil Koefisien Determinan $\left(\mathbf{R}^{2}\right)$}

\begin{tabular}{ccc}
\hline R & R Square & $\begin{array}{c}\text { Adjusted R } \\
\text { Square }\end{array}$ \\
\hline $0.691^{\mathrm{a}}$ & 0.478 & 0.470 \\
\hline Sumber $:$ Hasil pengolahan data dengan SPSS versi 22
\end{tabular}

Nilai Adjusted $R$ Square sebesar 0.470 atau $47 \%$ variabel independen mempengaruhi variabel dependen, sedangkan 53\% lainnya dipengaruhi oleh variabel lain yang tidak diteliti dalam penelitian ini.

\section{Uji Parsial (Uji t)}

Tabel 5. Hasil Uji Parsial (Uji t)

\begin{tabular}{cccc}
\hline Model & $\begin{array}{c}\text { Unstandardized } \\
\text { Coefficients } \\
\text { B }\end{array}$ & T & Sig. \\
\hline (Constant) & -0.717 & -0.663 & 0.508 \\
X1 & 0.064 & 4.057 & 0.000 \\
X2 & 0.081 & 5.583 & 0.000 \\
X3 & 0.259 & 6.115 & 0.000 \\
\hline \multicolumn{4}{c}{ Sumber : Hasil pengolahan data dengan SPSS versi 22}
\end{tabular}

Berdasarkan hasil uji parsial (uji t) . maka dapat dijelaskan sebagai berkut:

1. Pengaruh $\mathrm{X}_{1}$ terhadap $\mathrm{Y}$ memiliki nilai signifikan, karena nilai signifikan lebih kecil dari 0,05 yaitu 0,000 dan $t_{\text {hitung }}$ lebih besar dari $t_{\text {tabel }}$ yaitu 4,057. Dengan demikian hipotesis pertama $\left(\mathrm{H}_{1}\right)$ diterima, variabel pengetahuan SAK Entitas Mikro Kecil dan Menengah berpengaruh terhadap minat menggunakan aplikasi akuntansi.

2. Pengaruh $\mathrm{X}_{2}$ terhadap $\mathrm{Y}$ memiliki nilai signifikan, karena nilai signifikan kurang dari 0,05 yaitu 0,000 dan $t_{\text {hitung }}$ lebih besar dari $t_{\text {tabel }}$ yaitu 5,583. Dengan demikian hipotesis kedua $\left(\mathrm{H}_{2}\right)$ diterima, variabel Computer Selfefficacy berpengaruh terhadap minat menggunakan aplikasi akuntansi.

3. Pengaruh $\mathrm{X}_{3}$ terhadap $\mathrm{Y}$ memiliki nilai signifikan, karena nilai signifikan lebih kecil dari 0,05 yaitu 0,000 dan $t_{\text {hitung }}$ lebih besar dari $t_{\text {tabel }}$ yaitu 6,115 . Dengan demikian hipotesis ketiga $\left(\mathrm{H}_{3}\right)$ diterima, variabel Facilitating conditions berpengaruh terhadap minat menggunakan aplikasi akuntansi. 
Jurnal Akuntansi Berkelanjutan Indonesia - Vol. 3, No. 1, Jan 2020 - Defillaleti;

Sugiharto \& Umiyati

\section{Uji Simultan (Uji F)}

Tabel 6: Hasil Uji Simultan (Uji F)

\begin{tabular}{|c|c|c|c|}
\hline \multicolumn{4}{|c|}{ ANOVA $^{\mathrm{a}}$} \\
\hline & & $\mathrm{F}$ & Sig. \\
\hline 1 & $\begin{array}{l}\text { Regression } \\
\text { Residual } \\
\text { Total }\end{array}$ & 61.234 & $.000^{\mathrm{b}}$ \\
\hline
\end{tabular}

Dapat dilihat dalam tabel 6, nilai signifikan untuk ketiga variabel bebas yaitu 0,000 atau kurang dari 0,05 serta $\mathrm{F}$ hitung lebih besar daripada $\mathrm{F}$ tabel. Dapat disimpulkan bahwa variabel pengetahuan SAK Entitas Mikro Kecil dan Menengah (X1), Computer Self-efficacy (X2), dan Facilitating conditions (X3) berpengaruh secara simultan terhadap minat menggunakan aplikasi akuntansi.

\section{Pengaruh pengetahuan Standar Akuntansi Keuangan Entitas Mikro Kecil dan Menengah (SAK EMKM) terhadap minat menggunakan aplikasi akuntansi.}

Pengetahuan Standar Akuntansi Keuangan Entitas Mikro Kecil dan Menengah (SAK EMKM) berpengaruh positif terhadap minat menggunakan aplikasi akuntansi pada Usaha Mikro, Kecil, dan Menengah (UMKM) di Kabupaten Subang.

Hubungan antara kedua variabel ini menunjukan bahwa pengetahuan Standar Akuntansi Keuangan Entitas Mikro Kecil dan Menengah (SAK EMKM) menjadi faktor penting dalam melakukan penyusunan laporan keuangan dengan menggunakan aplikasi akuntansi, karena ilmu atau pengetahuan pengguna sangat membantu dalam pembuatan laporan keuangan agar sesuai dengan standar akuntansi keuangan yang berlaku. Hasil penelitian ini mendukung penelitian dari Rafiqa (2018).

Pengaruh Computer Self-efficacy terhadap minat menggunakan aplikasi akuntansi.

Adanya pengaruh antara Computer Self-efficacy terhadap minat. Computer Self-efficacy merupakan suatu kondisi di mana individu merasa mampu dan yakin dalam melakukan suatu kegiatan termasuk menggunakan komputer. Dengan demikian hasil penelitian ini mendukung penelitian dari Sudibyanto (2013), Chandra dan Rahmawati (2016), dan Lestari (2018).

\section{Pengaruh Facilitating conditions terhadap minat menggunakan aplikasi akuntansi.}

Facilitating conditions berpengaruh positif terhadap minat menggunakan aplikasi akuntansi pada Usaha Mikro, Kecil, dan Menengah (UMKM) di Kabupaten Subang. Kondisi-kondisi yang memfasilitasi penting untuk meningkatkan rasa ingin menggunakan aplikasi akuntansi dalam menyusun laporan keuangan perusahaan, dikarenakan tidak semua pelaku usaha mampu 
Jurnal Akuntansi Berkelanjutan Indonesia - Vol. 3, No. 1, Jan 2020 - Defillaleti;

Sugiharto \& Umiyati

atau mahir menggunakan aplikasi akuntansi untuk pertama kalinya. Penelitian ini mendukung penelitian dari Bendi dan Andayani (2013).

Pengaruh pengetahuan Standar Akuntansi Keuangan Entitas Mikro Kecil dan Menengah (SAK EMKM), Computer Self-Efficacy, dan Facilitating conditions terhadap minat menggunakan aplikasi akuntansi.

Pengetahuan Standar Akuntansi Keuangan Entitas Mikro Kecil dan Menengah (SAK EMKM), Computer Self-Efficacy, dan Facilitating conditions berpengaruh positif terhadap minat menggunakan aplikasi akuntansi pada Usaha Mikro, Kecil, dan Menengah (UMKM) di Kabupaten Subang.

\section{KESIMPULAN DAN SARAN} berikut:

Berdasarkan hasil analisis penelitian dapat ditarik kesimpulan sebagai

1. Hasil pengujian untuk variabel pengetahuan Standar Akuntansi Keuangan Entitas Mikro Kecil dan Menengah (SAK EMKM) berpengaruh positif terhadap minat menggunakan aplikasi akuntansi pada usaha mikro, kecil, dan menengah di Kabupaten Subang. Dengan demikian hipotesis pertama (H1) diterima.

2. Hasil pengujian untuk variabel Computer Self-efficacy berpengaruh positif terhadap minat menggunakan aplikasi akuntansi pada usaha mikro, kecil, dan menengah di Kabupaten Subang. Dengan demikian hipotesis kedua (H2) diterima.

3. Hasil pengujian untuk variabel Facilitating Conditions berpengaruh positif terhadap minat menggunakan aplikasi akuntansi pada usaha mikro, kecil, dan menengah di Kabupaten Subang.Dengan demikian hipotesis ketiga (H3) diterima.

4. Hasil pengujian secara bersamaan atau simultan untuk variabel pengetahuan Standar Akuntansi Keuangan Entitas Mikro Kecil dan Menengah (SAK EMKM), Computer Self-efficacy dan Facilitating conditions berpengaruh positif terhadap minat menggunakan aplikasi akuntansi pada usaha mikro, kecil, dan menengah di Kabupaten Subang. Dengan demikian hipotesis keempat (H4) diterima.

\section{DAFTAR PUSTAKA}

Ajzen, Icek. (1991). The theory of planned behavior. Organizational Behavior and Human Decision Processes, 50, 179-2 1 1. University of Massachusetts at Amherst.

Ajzen, Icek. (2002). Perceived Behavioral Control, Self-Efficacy, Locus of

* Corresponding author's e-mail: bambangsugihart@gmail.com

http://openjournal.unpam.ac.id/index.php/JABI 
Jurnal Akuntansi Berkelanjutan Indonesia - Vol. 3, No. 1, Jan 2020 - Defillaleti;

Sugiharto \& Umiyati

Control, and the Theory of Planned Behavior. Journal of Applied Social Psychology, 32, 4, pp. 665-683. University of Massachusetts at Amherst.

Andryanto, Reza., (2016). Pengaruh Kepercayaan, Persepsi Manfaat, dan Persepsi Kemudahan Penggunaan Terhadap Minat Beli di Toko Online (Studi Empiris yang dilakukan pada OLX.Co.id di Yogyakarta). Skripsi. Jurusan Manajemen, Universitas Negeri Yogyakarta.

Bandura, Albert. (1989). Human agency in social cognitive theory. American Psychologist, 44, 1 175- 11 84. Stanford University.

Chandra, Izhal Rio. dan Rahmawati, Diana. (2016). Pengaruh Kemudahan Penggunaan, Kepercayaan, Dan Computer Self Efficacy Terhadap Minat Penggunaan E- Spt Dalam Pelaporan Pajak. Jurnal Nominal / Volume V Nomor 1 / Tahun 2016. Akuntansi Universitas Negeri Yogyakarta

Compeau, D. R., dan Higgins, C. A. (1999). Social Cognitive Theory and Individual Reactions to Computing Technology: A Longitudinal Study. MIS Quarterly, Vol. 23, No. 2 (Jun., 1999), pp. 145-158. University of Minnesota.

Debbianita dan Sitorus, Dewi Novita. (2016). Analisis Determinan Tingkat Pengetahuan Pelaku UMKM mengenai SAK ETAP serta Pengaruhnya terhadap Kemudahan Akses ke Lembaga Keuangan. Jurnal Akuntansi Vol.8 No.1 Mei 2016: 86 - 104.

Dinas Koperasi dan Usaha Mikro, Kecil, dan Menengah Subang. 2018. Rekap update data KUMKM 2015, 2016, 2017.

Kementerian Koperasi dan Usaha Mikro, Kecil, dan Menengah. 2017. Perkembangan Data Usaha Mikro, Kecil, dan Menengah (UMKM) dan Usaha Besar (UB) Tahun 2012-2017.

Kementerian Koperasi dan Usaha Mikro, Kecil, dan Menengah.2008. UU No.20 Tahun 2008 Tentang UMKM. Jakarta.

Kurniawan, Andry Redima., Indrawati dan Djatmiko. T. (2016). Analisis faktorfaktor minat konsumen menggunakan aplikasi go-jek. e-Proceeding of Management: Vol.3, No.3 December 2016 Page 2850. Universitas Telkom.

Lestari, Elis. (2018). Pengaruh Persepsi Kemudahaan Penggunaan, Persepsi kebermanfaatan, Computer Self Efficacy, Facilitating Conditios dan Pengetahuan Akuntansi Terhadap Minat menggunakan software zahir (Studi Pada Usaha Dagang di Kabupaten Sukoharjo). Skripsi. Jurusan Akuntansi Syariah Fakultas Ekonomi Dan Bisnis Islam Institut Agama Islam Negeri Surakarta.

Maharsi. (2000). Pengaruh perkembangan teknologi informasi terhadap bidang akuntansi manajemen. Jurnal Akuntansi \& Keuangan Vol. 2, No. 2, 127 137.

Nurfadilah, Muhammad Ivan. (2018). Pemahaman dan Penyajian Standar Akuntansi Keuangan Entitas Tanpa Akuntabilitas Publik (SAK ETAP) pada

* Corresponding author's e-mail: bambangsugihart@gmail.com

http://openjournal.unpam.ac.id/index.php/JABI 
Jurnal Akuntansi Berkelanjutan Indonesia - Vol. 3, No. 1, Jan 2020 - Defillaleti;

Sugiharto \& Umiyati

Home Industry Kripik Tempe di Sentra Kripik Tempe Karangtengah Prandon Ngawi (tahun 2015-2016). Skripsi. Fakultas Ekonomi dan Bisnis Islam Program Studi Akuntansi Universitas Islam Negeri Sunan Ampel Surabaya.

Salmiah, N., et al. 2018. Pemahaman Pelaku Umkm Terhadap Sak Emkm : Survey Pada Umkm Yang Terdaftar Di Dinas Koperasi Dan Ukm Kota Pekanbaru. Akuntansi Dewantara Vol.2 No.2.

Venkatesh, V., Morris, M. G., Davis, G. B., dan Davis, F. D. (2003). User acceptance of information technology: Toward A Unified View1. MIS Quarterly Vol. 27 No. 3, pp. 425-478.

Venkatesh, V., Thong, J. Y. L., dan XinXu. (2012). Consumer Acceptance and Use of Information Technology: Extending the Unified Theory of Acceptance and Use of Technology. MIS Quarterly Vol. 36 No. 1 Pp. 157178/March2012, 36(1), 157-178. University of Minnesota. 